\title{
Photosynthesis and Productivity of Cyperus rotundus and Setaria viridis in the Three Gorges Reservoir Area: An Empirical Study
}

\author{
Jiang' en Shen \\ College of Biological \& Pharmaceutical \\ China Three Gorges University \\ Yichang, 443002, China \\ e-mail: 276518735@qq.com
}

\author{
Fangqing Chen*,Corresponding author. \\ College of Biological \& Pharmaceutical \\ China Three Gorges University \\ Yichang, 443002, China \\ e-mail: fqchen@ctgu.edu.cn
}

\begin{abstract}
Objective: To find adaptation strategies of a perennial herb Cyperus rotundus and an annual herb Setaria viridis, and evaluate their ability for the ecological restoration in the hydro-fluctuation belt in the Three Gorges reservoir area (TGR). Methods: An empirical study of photosynthesis and productivity of these two herbs was conducted. The study consisted of photosynthetic characteristics, chlorophyll and community productivity at altitude gradient from 150 to $180 \mathrm{~m}$ at $10 \mathrm{~m}$ interval which cover the flooding zone (altitude $150 \mathrm{~m}, 160 \mathrm{~m}$ and $170 \mathrm{~m}$ ) and no flooding zone (altitude $180 \mathrm{~m}$ ). Results: Perennial herb and annual herb have different adaption strategy for anti-seasonal water flooding, but both herbs were able to adapt flooding stress with the ability of photosynthesis recovery after flooding. The net photosynthesis rate $(P n)$ of both herbs have the highest values in shallow flooding zone (altitude $170 \mathrm{~m}$ ), and there was no significant difference existed between deep flooding zone (altitude $150 \mathrm{~m}$ ) and no flooding zone (altitude $180 \mathrm{~m}$ ). Chlorophyll also recovered, and is significant related with $P n(p<0.05)$. Besides, the community productivity of both herbs recovered after flooding, with community productivity of $C$. rotundus in shallow flooding zone was higher than that of no flooding zone, and community productivity of $S$. viridis in moderate flooding zone (altitude $160 \mathrm{~m}$ ) and deep flooding zone were higher than that of no flooding zone. Perennial herb enhance its tolerance to flooding by reducing biomass and enhancing their root growth, whereas annual herb mainly started its growth after flooding. Perennial herb also play an important role in water conservation in water fluctuating area by enhancing root growth. Conclusion: Taking together, $C$. rotundus and $S$. viridis both have good adaptation to antiseasonal water fluctuation in the TGR, and were appropriate species for ecological restoration in the hydro-fluctuation belt.
\end{abstract}

Keywords: Three Gorges reservoir area; Cyperus rotundus; Setaria viridis; photosynthetic characteristics; community productivity

\section{INTRODUCTION}

The construction of the Three Gorges Dam (TGD) forms the world's largest hydro-fluctuation belt in the Three Gorges reservoir area (TGR), with the area of $\sim 300$ $\mathrm{km} 2$ and the level of water fluctuation from $145 \mathrm{~m}$ in summer to $175 \mathrm{~m}$ in winter [1,2]. The hydrologic regime in TGR is opposite with the Yangtze River's natural regime before TGD construction, which dramatically alter environmental conditions in the hydro-fluctuation belt, and further change vegetation composition and type [3]. Thus, plant biodiversity in the hydro-fluctuation belt decreased seriously, and only a few plant species were able to survive and establish on the riverbank [4].

The dominant species in riverbank was herb, with only a little proportion of shrubs and trees [5]. Cyperus rotundus (a perennial herb) and Setaria viridis (an annual herb) are dominant herb species in the TGR, with good adaptation to anti-seasonal water fluctuation. These two herbs have different adaption strategy for anti-seasonal flooding, and might be appropriate candidates for ecological restoration in the hydro-fluctuation belt. However, insufficient research about their ecological restoration ability were found, especially for the annual herb Setaria viridis.

In the present study, we hope to find adaptation strategies of Cyperus rotundus and Setaria viridis to water fluctuation in the hydro-fluctuation belt of TGR, and evaluate their ability for the ecological restoration in the hydro-fluctuation belt. To this end, a series of field experiments was conducted, testing the photosynthesis and community productivity, together with their changes with altitude environmental gradient.

\section{TYPE MATERIALS AND METHOD}

\section{A. Study area.}

The study area located in Wangushi village $\left(30^{\circ} 97^{\prime} \mathrm{N}\right.$, $\left.110^{\circ} 76^{\prime} E\right)$, Zigui County, Yichang City, Hubei Province, China. The study area was inside in TGR, and within the drainage basin of Xiangxi river, one of the tributary of the Yangtze River. This area belongs to subtropical continental monsoon climate, with four distinct seasons. The annual average temperature is $17.1^{\circ} \mathrm{C}$, and the annual frost-free period lasting $217 \mathrm{~d}$. The average annual sunshine time is $1528 \mathrm{~h}$, which mostly concentrate in the summer (34\%). The annual rainfall is 900-1200 $\mathrm{mm}$, mostly concentrate in from March to October. Soil types are yellow soil and lime soil, with moderate fertility.

\section{B. Sample sites.}

Grassland dominated by $C$. rotundus and $S$. viridis was selected as sample sites, respectively. Each herb research 
consisted of 4 sample sites along with altitude gradient from 150 to $180 \mathrm{~m}$ at $10 \mathrm{~m}$ interval which cover the flooding zone (altitude $150 \mathrm{~m}, 160 \mathrm{~m}$ and $170 \mathrm{~m}$ ) and no flooding zone (altitude $180 \mathrm{~m}$ ). Each altitude was settled three $1 \times 1 \mathrm{~m}^{2}$ quadrats for each herb, then plant density was investigated in field at each quadrat.

\section{Photosynthesis characteristics.}

Photosynthesis and related physiological parameters of plant leaves were tested in sunning days on July 14. Five plants of each species were selected randomly from quadrats at the same altitude. Photosynthesis characteristics included the net photosynthesis rate $\left(\mathrm{P}_{\mathrm{n}}\right)$, transpiration rate $\left(\mathrm{T}_{\mathrm{r}}\right)$, stomatal conductance $\left(\mathrm{C}_{\mathrm{s}}\right)$, intercellular $\mathrm{CO}_{2}$ concentration $\left(\mathrm{C}_{\mathrm{i}}\right)$ were measured with a portable photosynthesis system (Model LI-6400, Li-Cor, Inc., USA) at the condition of air-temperature $\left(32-36{ }^{\circ} \mathrm{C}\right)$, relative humidity $(50-60 \%)$ and $\mathrm{CO}_{2}$ concentration (360$380 \mu \mathrm{mol} \mathrm{mol}-1$ ) [4]. The third leaf of each sampled plant was used for the determination, and each leaf was detected three times and mean value was obtained. Then, the samples plants were carefully dig out and taken back to laboratory.

\section{Chlorophyll content.}

Chlorophyll content in the third leaf of each sample plant $(0.2 \mathrm{~g})$ was abstracted with $80 \%$ acetone, and then measured by UV-1200 ultraviolet visible spectrophotometer (7). Each sample was detected three times and mean value was obtained to calculate the photosynthetic pigment contents per unit fresh weight of leaf.

\section{E. Plant biomass.}

Each sampled plant was separated into leaves, stem and root, respectively, and dried in oven for $15 \mathrm{~min}$ at $105^{\circ} \mathrm{C}$, then at $70^{\circ} \mathrm{C}$ until the samples reached constant weight. Each part biomass of $C$. rotundus and $S$. viridis was weighed. Community productivity of each species was calculated according with average plant biomass and plant density at each quadrat.

\section{F. Data processing.}

Data were presented means \pm SD $(n=5)$. Two-way analysis of variance was done on all the data to confirm the variability of data and validity of results using SPSS 15.0 software (SPSS, Inc., USA). Duncan's multiple range tests were performed to determine the significant difference between treatments at 0.05 and 0.01 probability.

\section{RESUltS}

\section{A. Photosynthetic characteristics.}

The photosynthesis changed significantly with the change altitude, $\mathrm{P}_{\mathrm{n}}$ variation of $C$. rotundus and $S$. viridis displayed similar trends that $170 \mathrm{~m}>180 \mathrm{~m}>160 \mathrm{~m}>150 \mathrm{~m}$ (Fig. 1A). Significant difference was found among the flooding zone (altitude $150 \mathrm{~m}, 160 \mathrm{~m}$ and $170 \mathrm{~m}, \mathrm{p}<0.05$ ) in both herbs. And $\mathrm{P}_{\mathrm{n}}$ at no flooding zone (altitude $180 \mathrm{~m}$ ) was higher than that at altitude $160 \mathrm{~m}$ for $\mathrm{C}$. rotundus but not $S$. Viridis, whereas $\mathrm{P}_{\mathrm{n}}$ at altitude $180 \mathrm{~m}$ were lower than those of altitude $170 \mathrm{~m}$, with $\mathrm{P}_{\mathrm{n}}$ at altitude $170 \mathrm{~m}$ was 1.20 and 1.22 folds those at altitude $180 \mathrm{~m}$ for $C$. rotundus and $S$. Viridis, respectively.
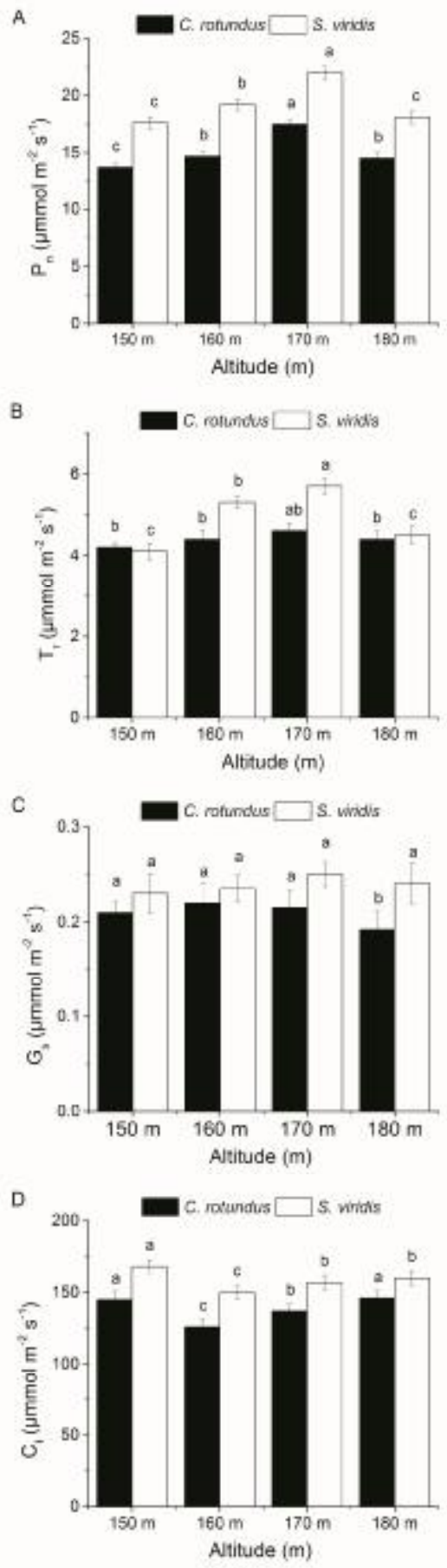

FIGURE.1: THE VARIATION OF PHOTOSYNTHETIC CHARACTERISTICS OF TWO HERBS. VALUES ARE MEAN $\pm \mathrm{SE}(\mathrm{N}=5)$. LETTERS INDICATED A SIGNIFICANT DIFFERENCE $(\mathrm{P}<0.05)$ AMONG DIFFERENT ALTITUDE.

$\mathrm{T}_{\mathrm{r}}$ of both herbs displayed similar spatial dynamics trends with $\mathrm{P}_{\mathrm{n}}$ each of species, with highest values both occurred at altitude $170 \mathrm{~m}$ (Fig. 1B). $\mathrm{G}_{\mathrm{s}}$ variation of $C$. rotundus wasn't significant among flooding zone but the difference between flooding zone and no flooding zone were significant $(p<0.05)$, with the lowest $\mathrm{G}_{\mathrm{s}}$ appeared at altitude $180 \mathrm{~m}$ (Fig. 1C). However, $\mathrm{G}_{\mathrm{s}}$ variation of $S$. viridis wasn't significant among all altitude zones. $\mathrm{C}_{\mathrm{i}}$ variation were opposite with $\mathrm{P}_{\mathrm{n}}$ for both herbs, with the 
values at altitude $160 \mathrm{~m}$ and $170 \mathrm{~m}$ were lower than those at altitude $150 \mathrm{~m}$ and $180 \mathrm{~m}$ (Fig. 1D).

$\mathrm{P}_{\mathrm{n}}$ of $C$. rotundus was significantly positively relative with $\mathrm{T}_{\mathrm{r}}(\mathrm{r}=0.931, \mathrm{p}<0.05)$ and $\mathrm{G}_{\mathrm{s}}(\mathrm{r}=0.694, p<0.05)$, and negative with $\mathrm{C}_{\mathrm{i}}(\mathrm{r}=-0.73, p<0.05)$, but no significant relationship was found between photosynthetic characteristics in S. Viridis.

\section{B. Chlorophyll content.}

The change of chlorophyll of two herbs both displayed similar trends that $170 \mathrm{~m}>180 \mathrm{~m}>160 \mathrm{~m}>150 \mathrm{~m}$ (Fig. 2). The variations of chlorophyll displayed the trend that $C$. rotundus $>S$. viridis. The highest values at altitude $170 \mathrm{~m}$ were 1.20 and 1.12 folds those at altitude $150 \mathrm{~m}$ for $C$. rotundus and $S$. viridis, respectively. A significantly correction was found between chlorophyll and $\mathrm{P}_{\mathrm{n}}$ in $C$. rotundus $(\mathrm{r}=0.735, p<0.05)$ and $S$. viridis $(\mathrm{r}=0.794$, $p<0.05)$.

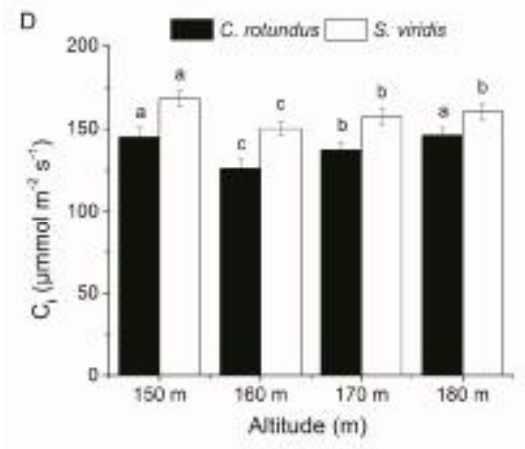

FIGURE. 2: THE VARIATION OF CHLOROPHYLL OF TWO HERBS' COMMUNITY. VALUES ARE MEAN $\pm \mathrm{SE}(\mathrm{N}=5)$. LETTERS INDICATED A SIGNIFICANT DIFFERENCE $(\mathrm{P}<0.05)$ AMONG DIFFERENT ALTITUDE.

TABLE 1: THE VARIATION OF COMMUNITY PRODUCTIVITY OF TWO HERBS. VALUES ARE MEAN $\pm \mathrm{SE}(\mathrm{N}=5)$. LETTERS INDICATED A SIGNIFICANT DIFFERENCE $(\mathrm{P}<0.05)$ AMONG DIFFERENT ALTITUDE.

\begin{tabular}{|c|c|c|c|c|c|}
\hline \multirow{2}{*}{ Species } & \multirow{2}{*}{$\begin{array}{c}\text { Altitude } \\
\text { (m) }\end{array}$} & \multicolumn{4}{|c|}{ Productivity $\left(\mathrm{g} \mathrm{m}^{-2}\right)$} \\
\hline & & Plant & Root & Stem & Leave \\
\hline \multirow{4}{*}{$\begin{array}{c}C . \\
\text { rotundus }\end{array}$} & 150 & $\begin{array}{l}1007.9 \\
\pm 41.2 \mathrm{~d}\end{array}$ & $\begin{array}{c}384.3 \\
\pm 16.8 \mathrm{a}\end{array}$ & $\begin{array}{c}229.5 \\
\pm 12.4 \mathrm{c}\end{array}$ & $\begin{array}{c}434.5 \\
\pm 21.7 \mathrm{~d}\end{array}$ \\
\hline & 160 & $\begin{array}{l}1109.7 \\
\pm 39.8 \mathrm{c}\end{array}$ & $\begin{array}{c}358.0 \\
\pm 17.4 \mathrm{~b}\end{array}$ & $\begin{array}{c}228.8 \\
\pm 14.5 \mathrm{c}\end{array}$ & $\begin{array}{c}503.4 \\
\pm 22.4 \mathrm{c}\end{array}$ \\
\hline & 170 & $\begin{array}{l}1218.7 \\
\pm 54.7 \mathrm{a}\end{array}$ & $\begin{array}{c}349.8 \\
\pm 14.3 \mathrm{~b}\end{array}$ & $\begin{array}{c}264.6 \\
\pm 17.3 \mathrm{a}\end{array}$ & $\begin{array}{c}629.5 \\
\pm 30.1 \mathrm{a}\end{array}$ \\
\hline & 180 & $\begin{array}{l}1165.7 \\
\pm 46.1 \mathrm{~b}\end{array}$ & $\begin{array}{c}324.1 \\
\pm 12.9 \mathrm{c}\end{array}$ & $\begin{array}{c}250.2 \\
\pm 13.4 \mathrm{~b}\end{array}$ & $\begin{array}{c}589.3 \\
\pm 28.5 \mathrm{~b}\end{array}$ \\
\hline$p$ & & $<0.01$ & $<0.01$ & $<0.01$ & $<0.01$ \\
\hline \multirow{4}{*}{$\begin{array}{c}S . \\
\text { viridis }\end{array}$} & 150 & $\begin{array}{c}960.4 \\
\pm 43.2 \mathrm{c}\end{array}$ & $\begin{array}{c}149.5 \\
\pm 10.2 \mathrm{c}\end{array}$ & $\begin{array}{r}672.3 \\
\pm 32.9 \mathrm{c}\end{array}$ & $\begin{array}{l}138.6 \\
\pm 8.9 \mathrm{~d}\end{array}$ \\
\hline & 160 & $\begin{array}{l}1022.3 \\
\pm 39.7 b\end{array}$ & $\begin{array}{c}157.5 \\
\pm 12.8 \mathrm{~b}\end{array}$ & $\begin{array}{c}710.4 \\
\pm 34.8 \mathrm{~b}\end{array}$ & $\begin{array}{c}154.4 \\
\pm 10.3 \mathrm{c}\end{array}$ \\
\hline & 170 & $\begin{array}{l}1073.1 \\
\pm 36.5 \mathrm{a}\end{array}$ & $\begin{array}{c}165.6 \\
\pm 10.4 \mathrm{a}\end{array}$ & $\begin{array}{r}733.9 \\
\pm 36.7 \mathrm{a}\end{array}$ & $\begin{array}{c}173.6 \\
\pm 13.4 \mathrm{a}\end{array}$ \\
\hline & 180 & $\begin{array}{l}1015.9 \\
\pm 40.2 b\end{array}$ & $\begin{array}{r}154.2 \\
\pm 11.2 \mathrm{~b}\end{array}$ & $\begin{array}{c}696.2 \\
\pm 31.2 \mathrm{~b}\end{array}$ & $\begin{array}{r}165.5 \\
\pm 12.1 \mathrm{~b}\end{array}$ \\
\hline$p$ & & $<0.01$ & $<0.01$ & $<0.01$ & $<0.01$ \\
\hline
\end{tabular}

C. Community productivity.
TABLE 2: THE VARIATION OF PRODUCTIVITY PROPORTION OF TWO HERBS' COMMUNITY. VALUES ARE MEAN $\pm \mathrm{SE}(\mathrm{N}=5)$. LETTERS INDICATED A SIGNIFICANT DIFFERENCE $(\mathrm{P}<0.05)$ AMONG DIFFERENT ALTITUDE.

\begin{tabular}{|c|c|c|c|c|c|}
\hline \multirow[b]{2}{*}{ Species } & Altitude & \multicolumn{4}{|c|}{ Productivity Propotion (\%) } \\
\hline & & Root & Stem & Leave & $\begin{array}{c}\text { Aboveground } \\
\text { /Underground } \\
\text { productivity }\end{array}$ \\
\hline \multirow{4}{*}{$\begin{array}{c}\text { C. } \\
\text { rotundus }\end{array}$} & 150 & $\begin{array}{c}35.2 \\
\pm 2.3 \mathrm{a}\end{array}$ & $\begin{array}{c}22.4 \\
\pm 1.8 \mathrm{a}\end{array}$ & $\begin{array}{c}42.4 \\
\pm 2.9 \mathrm{c}\end{array}$ & $\begin{array}{c}1.84 \\
\pm 0.12 \mathrm{c}\end{array}$ \\
\hline & 160 & $\begin{array}{c}31.8 \\
\pm 2.8 \mathrm{~b}\end{array}$ & $\begin{array}{c}21.8 \\
\pm 1.4 \mathrm{a}\end{array}$ & $\begin{array}{c}46.5 \\
\pm 4.2 \mathrm{~b}\end{array}$ & $\begin{array}{c}2.24 \\
\pm 0.13 \mathrm{~b}\end{array}$ \\
\hline & 170 & $\begin{array}{c}28.7 \\
\pm 2.6 \mathrm{c}\end{array}$ & $\begin{array}{c}21.1 \\
\pm 1.9 \mathrm{~b}\end{array}$ & $\begin{array}{c}50.2 \\
\pm 3.3 \mathrm{a}\end{array}$ & $\begin{array}{c}2.48 \\
\pm 0.09 \mathrm{a}\end{array}$ \\
\hline & 180 & $\begin{array}{c}27.9 \\
\pm 2.3 \mathrm{c}\end{array}$ & $\begin{array}{l}21.0 \\
\pm 1.5 \mathrm{a}\end{array}$ & $\begin{array}{c}51.1 \\
\pm 3.7 \mathrm{a}\end{array}$ & $\begin{array}{c}2.58 \\
\pm 0.11 \mathrm{a}\end{array}$ \\
\hline$p$ & & $<0.01$ & $<0.01$ & $<0.01$ & $<0.01$ \\
\hline \multirow{4}{*}{$\begin{array}{c}S . \\
\text { viridis }\end{array}$} & 150 & $\begin{array}{c}15.6 \\
\pm 2.4 \mathrm{a}\end{array}$ & $\begin{array}{c}70.0 \\
\pm 4.3 \mathrm{a}\end{array}$ & $\begin{array}{c}14.4 \\
\pm 1.4 \mathrm{c}\end{array}$ & $\begin{array}{c}5.42 \\
\pm 0.24 \mathrm{a}\end{array}$ \\
\hline & 160 & $\begin{array}{c}15.4 \\
\pm 3.1 \mathrm{a}\end{array}$ & $\begin{array}{c}69.5 \\
\pm 3.8 \mathrm{a}\end{array}$ & $\begin{array}{c}15.1 \\
\pm 2.1 \mathrm{~b}\end{array}$ & $\begin{array}{c}5.49 \\
\pm 0.19 \mathrm{a}\end{array}$ \\
\hline & 170 & $\begin{array}{c}15.4 \\
\pm 2.2 \mathrm{a}\end{array}$ & $\begin{array}{c}68.4 \\
\pm 4.5 \mathrm{a}\end{array}$ & $\begin{array}{c}16.2 \\
\pm 1.9 \mathrm{a}\end{array}$ & $\begin{array}{c}5.48 \\
\pm 0.25 \mathrm{a}\end{array}$ \\
\hline & 180 & $\begin{array}{c}15.1 \\
\pm 2.7 \mathrm{a}\end{array}$ & $\begin{array}{c}68.5 \\
\pm 5.1 \mathrm{a}\end{array}$ & $\begin{array}{c}16.3 \\
\pm 1.2 \mathrm{a}\end{array}$ & $\begin{array}{c}5.59 \\
\pm 0.21 \mathrm{a}\end{array}$ \\
\hline$p$ & & $<0.01$ & $<0.01$ & $<0.01$ & $<0.01$ \\
\hline
\end{tabular}

\section{DISCUSSION}

Photosynthesis and productivity recovery are important indicators to determine the physiological and biochemical adaptability of plants to flooding, and generally used to evaluated plant ability for the ecological restoration in the hydro-fluctuation belt $[4,6]$. In the present study, accurate assessment of a perennial herb $C$. rotundus and an annual herb $S$. viridis were conducted through an empirical study consisted of photosynthetic characteristics, chlorophyll and community productivity at altitude gradient.

First, photosynthetic characteristics was used to evaluated photosynthesis recovery. In this study, $\mathrm{P}_{\mathrm{n}}$ of $C$. rotundus and $S$. viridis both have the highest values in shallow flooding zone (altitude $170 \mathrm{~m}$ ), and there was no significant difference existed between deep flooding zone (altitude $150 \mathrm{~m}$ ) and no flooding zone (altitude $180 \mathrm{~m}$ ). $\mathrm{P}_{\mathrm{n}}$ of perennial herb and annual herb both recovered quickly after the flooding. Besides, $\mathrm{P}_{\mathrm{n}}$ of $C$. rotundus was significantly positively relative with $\mathrm{T}_{\mathrm{r}}$ and $\mathrm{G}_{\mathrm{s}}(p<0.05)$, and negative with $C_{i}(p<0.05)$, which was consisted with previous report about other perennial herbs [8,9]. However, no such significant relationship was found between photosynthetic characteristics in $S$. viridis. These results suggested that perennial herb and annual herb have different adaption strategy for anti-seasonal water flooding, but both herbs were able to adapt flooding stress with the ability of photosynthesis recovery after flooding.

Second, chlorophyll is an important indicator for photosynthesis, chlorophyll variation in these two herbs were also researched. The result showed that the decrease of chlorophyll was related the water depth and the time lasted in flooding period [7,10]. Chlorophyll variation was relatively tiny (1.20 and 1.12 folds, respectively), and was significant related to $\mathrm{P}_{\mathrm{n}}$ in both $C$. rotundus and $S$. viridis $(p<0.05)$. Taken together with chlorophyll and 
photosynthetic characteristics, both herbs were able to recovered their photosynthesis after flooding, even after the deepest water flooding (altitude $150 \mathrm{~m}$ ).

Third, perennial herb in the hydro-fluctuation belt enhance its tolerance to flooding by reducing biomass $[11,12]$. In the present study, the community productivity of $C$. rotundus in deep flooding zone (altitude $150 \mathrm{~m}$ ) and moderate flooding zone (altitude $160 \mathrm{~m}$ ) were lower than that of no flooding zone (altitude $180 \mathrm{~m}$ ), and in shallow flooding zone (altitude $170 \mathrm{~m}$ ) was higher than that of no flooding zone. Whereas the community productivity of $S$. viridis in shallow flooding zone and moderate flooding zone were higher than that of no flooding zone. This could be interpreted that the exchange of nutrients caused by flooding, which could enhance the growth of two herbs [13]. C. rotundus strengthen its root growth in moderate flooding zone and deep flooding zone significantly $(p<0.05)$ while $S$. viridis not, showed the adaption difference between perennial herb and annual herb. Perennial herb enhance its tolerance to flooding by reducing biomass and enhancing their root growth, whereas annual herb mainly started its growth after flooding [9-11]. The adaption mode of perennial herb meet the needs of nutritional for plant growth after flooding, and make it play an important role in water conservation in water fluctuating area [14]. Leaf productivity proportion and aboveground/underground productivity ratio of both herbs increased with increasing altitude, the accumulation of photosynthetic products were enhanced to release flooding stress as soon as possible $[9,10]$.

\section{CONCLUSIONS}

C. rotundus and $S$. viridis showed different adaptation strategies to anti-seasonal flooding, but their photosynthesis both recovered even in the deep flooding zone, with relatively tiny variation related to no flooding zone. The community productivity of both herbs recovered after flooding, with community productivity of $C$. rotundus in shallow flooding zone was higher than that of no flooding zone, and community productivity of $S$. viridis in moderate flooding zone and deep flooding zone were higher than that of no flooding zone. Perennial herb enhance its tolerance to flooding by reducing biomass and enhancing their root growth, whereas annual herb mainly start growth after flooding. The enhanced root growth of perennial herb in flooding conditions have an important role in water conservation in water fluctuating area. These results indicated that $C$. rotundus and $S$. viridis both had good adaptation to anti-seasonal water fluctuation in TGR, and were appropriate species for ecological restoration in the hydro-fluctuation belt.

\section{ACKNOWLEDGEMENTS}

This work is supported by China national Natural Science Foundation Project (51379105).

\section{REFERENCES}

[1] Chen, F. Q., Xie, Z. Q., Xiong, G. M., Liu, Y. M., \& Yang, H. Y. Reintroduction and population reconstruction of an endangered plant Myricaria laxiflora in the Three Gorges Reservoir area, China. Acta Ecologica Sinica, 25(7), pp. 1811-1817, 2005.

[2] Chen, F. Q., \& Xie, Z. Q. Reproductive allocation, seed dispersal and germination of Myricaria laxiflora, an endangered species in the Three Gorges Reservoir area. Plant Ecology, 191(1), pp. 67-75, 2007.

[3] Dai, F. X., Xu, W. N., \& Chen, F. Q. (2006). Pondering over falling zone ecosystem of Sanxia Reservoir and its ecological rehabilitation. Soil and Water Conservation in China, 27(12), pp. 6$8,2006$.

[4] Chen, F. Q., \& Xie, Z. Q. Survival and growth responses of Myricaria laxiflora seedlings to summer flooding. Aquatic Botany, 90(4), pp. 333-338, 2009.

[5] Wang, Y., Wu, J., Huang, H., \& Liu, S. Quantitative analysis of plant communities in water-level-fluctuation zone within Three Gorges reservoir area of Changjiang River. Plant Sciences Journal in China, 22(4), 307-314, 2003.

[6] Liu, Z. B., Cheng, R. M., Xiao, W. F., Guo, Q. S., \& Wang, N. (2014). Effect of off-Season flooding on growth, photosynthesis, carbohydrate partitioning, and nutrient uptake in Distylium chinense. PloS one, 9(9), e107636, 2014.

[7] Li, X. L., Li, N., Yang, J., Ye, F. Z., Chen, F. J., \& Chen, F. Q., Morphological and photosynthetic responses of riparian plant Distylium chinense seedlings to simulated Autumn and Winter flooding in Three Gorges Reservoir Region of the Yangtze River, China. Acta Ecologica Sinica, 31(1), pp: 31-39, 2011.

[8] Tan, S. D., Zhu, M. Y., Dang, H. S., Wang, Y., \& Zhang, Q. F. Physiological responses of bermudagrass [Cynodon dactylon (L.) Pers.] to deep submergence stress in the Three Gorges Reservoir Area. Acta Ecologica Sinica, 29(2), pp: 3685-3691, 2009.

[9] Chen, F. Q., \& Xie, Z. Q. Ecophysiological response of two hrebaceous species to flooding-implication for ecological vegetation restoration on the water-level-fluctuating zone in the Three Gorges reservoir area. 2011 International Conference on Electronics, Communications and Control, pp: 4260-4263. doi:10.1109/ICECC.2011.6068010.

[10] Liao, J., Jiang, M., \& Li, L. Effects of simulated submergence on survival and recovery growth of three species in water fluctuation zone of the Three Gorges reservoir. Acta Ecologica Sinica, 30(4), pp: 216-220, 2010.

[11] Hong, M., Guo, Q. S., Nie, B. H., Kang, Y., Pei, S. X., Jin, J. Q., \& Wang, X. F., Responses of Cynodon dactylon population in hydrofluctuation belt of Three Gorges Reservoir area to flooding-drying habitat change, Chinese Journal of Applied Ecology, 22(11), pp: 2829-2835. 2011.

[12] Hong, M., Guo, Q. S., Nie, B. H., Kang, Y., \& Pei, S. X. Responds of Cyperus rotundus to flooding-drying habit changes in Three Gorges Reservoir hydro-fluctuation belt [J]. Journal of Agricultural University of Hebei, 34(3), pp: 77-84, 2011.

[13] Wang, X. R., Cheng, R. M., Xiao, W. F., Guo, Q. S., \& Feng, X. H., Soil nutrient characteristics in juvenile water level fluctuating zone of Three Gorges Reservoir. Chinese Journal of Ecology, 29(2), pp: 281-289, 2010.

[14] Xu, S. J., \& Su, X. L., Root features of Several Flooding-tolerant Plants and their roles in enhancing anti-erodibility of the soil in three gorges reservoir region. Acta Ecologica Sinica, 18(1), pp: 160-165, 2011. 